\title{
Determinant of Parents Role in Adolescent Premarital Sex Behavior: An Applicative Model
}

\section{Determinan Peran Orang Tua terhadap Perilaku Seks Pranikah Remaja: Sebuah Model Aplikatif}

\author{
Nur Alam Fajar ${ }^{*}$, Fenny Etrawati², Widya Lionita ${ }^{3}$ \\ ${ }^{1}$ Departemen Promosi Kesehatan dan Ilmu Perilaku, FKM Universitas Sriwijaya \\ ${ }^{2,3}$ Departemen Promosi Kesehatan dan Ilmu Perilaku, FKM Universitas Sriwijaya \\ (*nuralamfajar@fkm.unsri.ac.id)
}

\begin{abstract}
Premarital sex behavior had become a serious issue. Preliminary studies show 12 of 30 teenagers who religious, well-educated, and has good family background, were already experienced sexual intercourse. The objective of this study is explaining parents' role through their knowledge, attitude, perception, facilities given to children, and behavior. This research was conducted at 2017, and using a cross-sectional design. Quantitative data were obtained by 526 population study and interviewing 150 students' parent from six high schools in Palembang which are selected using multistage random sampling. Multivariate data analysis is processed by Structural Equation Modelling (SEM) Test in statistical application program named Partial Least Square (PLS). This research found that fifty percent of respondent have good knowledge and supportive attitude towards preventive action of premarital sex behavior. There are $62.7 \%$ having good perception about the importance of parents' role. However, $41.3 \%$ just perform negatively on preventive sexual behavior in early ages. They usually provide some facilities such as money, motorbike or car, handphone, laptop, and internet at home that can be used to access pornography content. Model analysis proved that knowledge, attitude, perception, and facilities influence 29 percent of adolescent premarital sex behavior caused by improper parenting role. Keywords: Parenting, premarital sex behavior, teenagers
\end{abstract}

\section{ABSTRAK}

Perilaku seks pranikah telah menjadi permasalahan yang serius. Studi pendahuluan menunjukkan sebanyak 12 dari 30 remaja yang tergolong religious, berpendidikan baik, dan berasal dari keluarga yang baik, pernah melakukan hubungan seksual. Tujuan dari penelitian ini adalah untuk menjelaskan peran pola asuh orang tua yang dilihat melalui pengetahuan, sikap, persepsi, fasilitas yang disediakan, dan perilaku. Penelitian ini dilakukan pada 2017 dengan rancangan cross-sectional. Data kuantitatif diperoleh dari populasi 526 dan melakukan wawancara kepada 150 orang tua murid yang berasal dari enam sekolah menengah atas di Palembang yang dipilih menggunakan multistage random sampling. Analisis data multivariat diproses menggunakan uji Structural Equation Modelling (SEM) pada program aplikasi statistik bernama Partial Least Square (PLS). Penelitian ini menemukan bahwa lima puluh persen responden memiliki pengetahuan yang baik dan sikap mendukung terhadap tindakan pencegahan perilaku seks pranikah. Sebanyak $62.7 \%$ memiliki persepsi yang baik tentang pentingnya peran orang tua. Namun, $41.3 \%$ masih menunjukkan perilaku negatif pada pencegahan perilaku seks sedini mungkin. Orang tua biasanya menyediakan beberapa fasilitas seperti uang, sepeda motor atau mobil, telepon genggam, laptop, dan internet di rumah yang dapat digunakan untuk mengakses konten pornografi. Analisis model membuktikan bahwa pengetahuan, sikap, persepsi, dan fasilitas mempengaruhi sebesar $29 \%$ perilaku seks pranikah pada remaja yang diakibatkan oleh pola asuh orang tua yang tidak tepat.

Kata kunci : Pola asuh, seks pranikah, remaja 


\section{INTRODUCTION}

The productivity of human resources, especially in the productive age group will affect the development of a country. Growth and development of adolescent quality are the important elements as a benchmark and foundation of national hopes, but in the health and social fields, these groups are susceptible to various problems, especially related to juvenile delinquency and negative behaviour. If there is no control it will destroy their future. Some examples of adolescent problems are physical violence (bullying, fighting), narcotics and drug abuse, premarital sexual behavior and so on.

The development and sexual drive felt by adolescents are biologically reasonable but if there is a good control it will lead to negative behaviour, they will try to experiment through the courtship status and usually many of them eventually fall into promiscuity. ${ }^{1}$ Premarital sexual behaviour among adolescent was found in almost all major cities in Indonesia, regardless of ethnicity, religion or even education level background. They do not feel embarrassed, sinned and nodded, they think that's normal condition without thinking about the risk of sexually transmitted disease or the occurrence of unwanted pregnancies. A study in Palembang City illustrates the results that there is 79 percent of students who have courtship status say that they were doing premarital sex together. ${ }^{2}$

Adolescence starts from the age of 11 to 20 years which is the transition phase from children to adults, at that age is usually characterized by the maturity of the reproductive organs. At that time they tried to shape their identity in their family and social interaction. Usually along with their development, they will try to show that they have been able to be independent and can decide what is good and bad for their future. In adolescence, a strong self-concept is very important because peer interactions and influences are very vulnerable. Meanwhile the self-concept of adolescence is formed from the realization of the role and function of the family, especially the parents so that inappropriate family care becomes one of the factors that determine the cause of premarital sexual behaviour among adolescents. ${ }^{3}$

A poor understanding of parents' about reproductive health, causes teenagers to usually find their information either from books, the media, and even their friends. It can be the cause of negative behaviour of adolescent. So the parent's control becomes a significant factor to preventing premarital sexual behaviour in adolescents. ${ }^{4}$ A study at Palembang High School found that attitudes, education, and communication of parents and children were positively correlated with adolescent knowledge about premarital sexual behaviour. ${ }^{5}$

Parents are one of the closest to adolescents, that's why parents must be a filter of the influence of values and negative information that comes from facilities such as television and gadgets. ${ }^{6}$ One of the important adolescents needed is spiritual values by parents such as religious guidance to avoid negative society because adolescents are more trusting of their parents or family members as the main source of information about sexual health. ${ }^{7}$ The aims of this study are to describe attitudes, knowledge, perceptions, availability of facilities, as well as modelling parenting styles related to premarital sexual behaviour of adolescents which is conducted in Palembang City.

\section{METHODS}

The research was a quantitative study using a cross-sectional design with a multi-stage random sampling selection. The population of the study was 526 parents from high school, vocational or Madrasah Aliyah, both of public and private school in Palembang City. Sample study was taken from one public high school and one private high school with 150 respondents. The inclusion criteria were students who lived with their parents, had or were dating status during the study period.

The study variable contains were parents' knowledge about adolescent reproductive health, attitudes, perceptions, and facilities provided by parents, while the outcomes are premarital sex behaviour. Collection data using a questionnaire by interview parents. Bivariate and multivariate data analysis using the Structural Equation Modelling (SEM) test with Partial Least Square program.

\section{RESULT}

Most of respondents in this study are women $(73,3 \%)$, so more than half of them are housewife $(57,3 \%)$. Their education levels are various, from post-graduate degree to no school at all. 
About 42,7 percent of respondents are graduated from Senior High School. In the other hand, they were categorized ad Moslem (99,3 \%) (Table 1).

Parents knowledge about adolescent's reproductive health referred to definition of puberty, primary and secondary characteristics of puberty, type of sexual behavior and its negative effect that generally done by teenager. The results show that half of respondents has good knowledge about adolescent's reproductive health. Their knowledge's score is distributed from 7 until 18 points with mean score is about 15.18 (95\%CI:14.87-15.49) (Table 2).

Fifty percent of respondents already have supportive attitude to prevent their children from premarital sexual behavior. They believe the important role of parents is controlling children behavior by giving early sex education. This attitude is in line with perception about the importance of their role as parents which more than half of them $(62,7 \%)$ are classified 'good' (95\%CI:29.7930.87) (Table 2).

Parents usually provide their children with some facilities, such as money, motorbike or car, handphone, laptop, internet at home and refreshment like family recreation. In this study, about 58

Table 1. Characteristics of Respondents

\begin{tabular}{lcc}
\hline \multicolumn{1}{c}{$\begin{array}{c}\text { Characteristics of } \\
\text { Respondents }\end{array}$} & \multicolumn{2}{c}{ Amount } \\
\cline { 2 - 3 } Gender & $\mathbf{n}$ & $\mathbf{\%}$ \\
$\quad$ Father & 40 & 26,7 \\
$\quad$ Mother & 110 & 73,3 \\
Education & & \\
$\quad$ No school & 4 & 1,7 \\
$\quad$ Elementary school & 32 & 21,3 \\
$\quad$ Junior high school & 33 & 22 \\
$\quad$ Senior High school & 64 & 42,7 \\
$\quad$ Diploma degree (D1/D3) & 3 & 2 \\
$\quad$ Under-graduate (S1) & 12 & 8 \\
$\quad$ Post-graduate (S2) & 2 & 1,3 \\
Religion & & \\
$\quad$ Islam & 149 & 99,3 \\
$\quad$ Catholic & 1 & 0,7 \\
Job & & \\
$\quad$ Workers/casual daily workers & 26 & 17,3 \\
$\quad$ Entrepreneur/Trader & 21 & 14 \\
Civil servants & 10 & 6,7 \\
Private employees & 7 & 4,7 \\
Others (Housewives) & 86 & 57,3 \\
\hline
\end{tabular}

Table 2. Knowledge, Attitude, Perception and Facilities related to Adolescent Premarital Sex Behavior

\begin{tabular}{|c|c|c|c|c|}
\hline \multirow{2}{*}{ Variabel } & \multicolumn{2}{|c|}{ Amount } & \multirow{2}{*}{ Mean } & \multirow{2}{*}{$95 \%$ CI } \\
\hline & $\mathbf{n}$ & $\%$ & & \\
\hline \multicolumn{5}{|l|}{ Knowledge } \\
\hline Low & 75 & 50 & 15.18 & $14.87-15.49$ \\
\hline High & 75 & 50 & & \\
\hline \multicolumn{5}{|l|}{ Attitude } \\
\hline Doesn’t Support & 75 & 50 & 29.4 & $28.92-29.88$ \\
\hline Support & 75 & 50 & & \\
\hline \multicolumn{5}{|l|}{ Perception } \\
\hline Wrong & 56 & 37,3 & 30.33 & $29.79-30.87$ \\
\hline Right & 94 & 62,7 & & \\
\hline \multicolumn{5}{|l|}{ Facilities } \\
\hline Negative & 63 & 42 & 4.09 & $3.78-4.4$ \\
\hline Positive & 87 & 58 & & \\
\hline
\end{tabular}

Table 3. Parenting Behavior related to Adolescent Premarital Sex Behavior

\begin{tabular}{lcccc}
\hline \multirow{2}{*}{ Parenting Behavior } & \multicolumn{2}{c}{ Amount } & \multirow{2}{*}{ Mean } & \multirow{2}{*}{ 95\% CI } \\
\cline { 2 - 3 } & $\mathbf{n}$ & $\mathbf{\%}$ & & \\
\hline Negative & 62 & 41,3 & 18.11 & $17.54-18.68$ \\
Positive & 88 & 58,7 & & \\
\hline
\end{tabular}

percent of respondents give all or some facilities for positive purposes ( $95 \%$ CI:3.78-4.4) (see Table 2).

Positive behavior towards preventive actions of premarital sex is pictured by 58.7 percent of respondents. Parents regularly check children's reading, bag and clothes after school. They also pay attention for their children's close friend and daily activities (95\% CI:17.54-18.68) (see Table $3)$.

The Multivariate analysis illustrated in Figure 1 shows that behavioral variables are influenced by parental perception, knowledge, attitudes and facilities with $\mathrm{R}^{2}$ value of 0.29 meaning that independent variables have contribution towards behavior of $29 \%$. Knowledge is influenced by the facility and parental perception with $\mathrm{R}^{2}$ value of 0.247 which means that the facility and parental perception are $24.7 \%$ have contribution towards increased of knowledge. Attitudes are influenced by knowledge with $\mathrm{R}^{2}$ value of 0.244 which means that knowledge is $24.4 \%$ contribution towards increased of attitude. The pathway analysis can be concluded that the perception of parents and fa- 


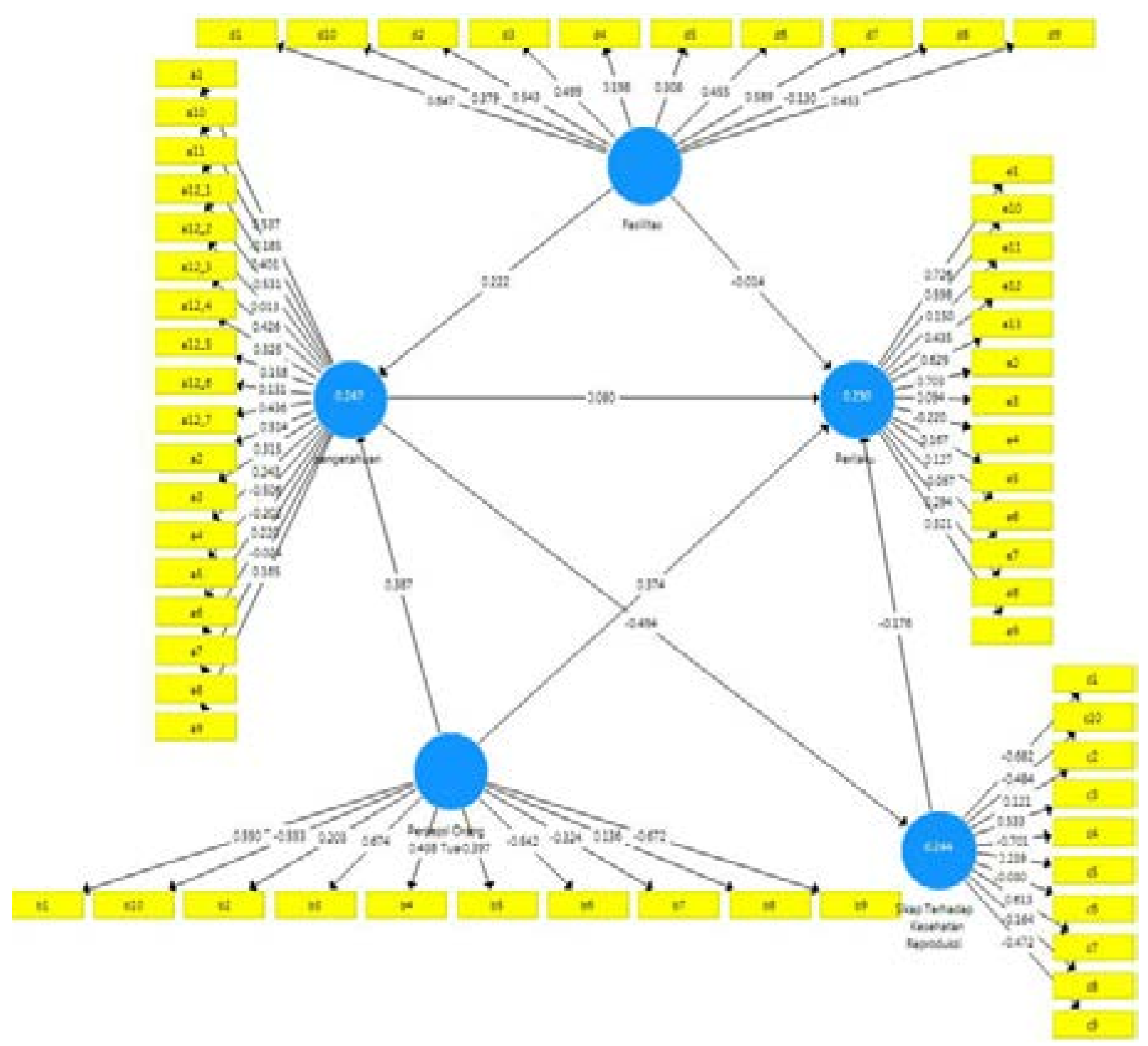

Figure 1. Variable Modeling of Parenting Behavior

cilities affects knowledge, while knowledge affects attitudes, and attitudes affect behavior. The strongest correlation between the 2 variables is correlation between knowledge and attitude with $\mathrm{R}$ value is 0.494 which means the higher knowledge, attitude towards reproductive health will be increased. Variables that are strongly correlated to behavior directly are the perception of parents with $R$ value is 0.394 which means the better perception of parents then his behavior will also be better (Figure 1).

\section{DISCUSSION}

The phenomenon in this study shows that parents have limited knowledge about the im- portance of maintaining adolescent reproductive health. This has an impact on communication patterns in the context of their adolescent sex education. On the other hand, only a small percentage of parents have a warm and open parenting pattern, and consistently enforce discipline to children. This has an impact on the pattern of giving appreciation or rational punishment when adolescents commit violations that have been mutually agreed upon. In this condition, free children become more open to their opinions, feelings and desires and teens are taught to be responsible for their choice of actions ${ }^{8}$.

Sexual socialization parents can influence a child's decision regarding premarital sexual 
behavior ${ }^{9}$. There is a significant relationship between knowledge and communication with parents with adolescent sexual practices, so parents can promote friendly family conditions so they must be able to create open communication about reproductive health and sexuality ${ }^{10}$.

Two third of the number parents participating in the study have a correct perception regarding the importance of parental involvement in limiting risk behavior in adolescents because the environment of family is a primary area in determining adolescent behavior. In Ethiopia it was found that there was a significant gap between how many parents tried to monitor their children about activities and how much they actually knew. Furthermore, the study found that most parents describe a negligent parenting style, which means that children look down on their parents in terms of support and control or monitoring ${ }^{11}$. A study of teen parents communication in China shows that adolescents at this time express a tendency to avoid sex-related communication with parents 12. They must improve communication at home which will encourage healthy information choices among adolescents, while the practice of their children is still considering lack ${ }^{13}$.

Sexual behavior among adolescents is inseparable from the availability of facilities that make it easy for teenagers including money, vehicles, cellphones and so on. Half of the total respondents (58\%) claimed to provide the facilities in question. Supposedly the parents do not give excessive facilities to adolescents because of the bias so without the supervision of parents, teens abusing these facilities until mired in premarital sexual behavior ${ }^{2}$. Studies in Vietnam show that the factors that influence adolescent involvement in premarital sexual behavior such as direct causes, facilitators, changes in the social environment, the media, peers and families ${ }^{14}$.

Lack of control over the provision of various facilities that are material to children is the result of errors in parenting teenagers. Researchers found that almost $40 \%$ of respondents gave teenagers the freedom to behave. Based on other research references in Samarinda it was proven that premarital sexual behavior was triggered by the wrong type of parenting. Parents must apply an authoritative type so that teenage premarital be- havior can be minimized ${ }^{15}$.

Parenting errors in related adolescents have a correlation to the adjustment or formation of children's behavior ${ }^{16}$. Parenting practices that are applied by parents if they are too free will make it easier for teenagers to take wrong actions ${ }^{8}$. In line with the research in Padang, it was proven that caregiving was the most dominant variable influencing the habit of sexual behavior when compared to demographic factors, knowledge and partners (girlfriends) of adolescents ${ }^{17}$. The recommendation of a study in Pekanbaru on premarital sexual problems is to adopt an open (democratic) parenting style but still pay attention to signs that should not be violated in other words, still must be under the supervision of parents ${ }^{6}$.

Openness between parents and teens indicates patterns of interaction and good parenting. Negligence of parents in monitoring a teenager an opportunity for children to try sexual intercourse. According to Mesche, the delay in the age of the first sexual relationship in a child related to his parenting pattern where those who apply conservative parenting types (seen from the relationship between adolescents and parents) tends to be more protected to try sexual relations when they are compared to those who apply authoritarian parenting . Therefore, personality and behavior of children is the end result of various forms of care carried out by parents ${ }^{17}$.

Harlock in his book classify parenting styles into three categories namely authoritarian, democratic and permissive. Parents who apply the pattern of democratic care tend to give recognition / trust in the abilities of children so that children are formed into independent individuals ${ }^{18}$. Individual experience during the process of self-development becomes mature will shape self-concept in adolescents ${ }^{19}$. Based on research in Tuban it is known that adolescents who have a high self-concept $(81.5 \%)$ come from families that adopt democratic parenting instead of adopting parenting authoritarian tend to form children who have low self-concept.

Along with the development of adolescents, emotional factor is the most prominent changes. Scientifically, emotions are formed from the body's reaction/response in response to things that happen in an individual's environment. Increased emotional 
tension in adolescents is a manifestation of physical changes and glands (hormones) in themselves. At this age, the frequency of emotional outbursts is increasing which can be seen from angry reactions when facing a situation that has never been faced. Confidence in adolescents in controlling emotions can be involved from patterns of positive interactions that occur among adolescents or between adolescents and parents and the tendency to think positively. This shows that high student confidence in adolescents increases risky behavior / juvenile delinquency in adolescents ${ }^{18}$. Similar to the findings of research in Malang that the level of self-confidence influences the occurrence of premarital sexual behavior ${ }^{20}$.

In general, parenting in the family is very much influenced by the factors of closeness of the relationship between parents (primary caregivers) and other caregivers (secondary caregivers) to the children who are touched so that they can optimize the formation of positive values in adolescents and need to be supported by the principle of obedience to the commandments of religion, belief, and cultural values so as to form a strong adolescent personality.

\section{CONCLUSION AND RECOMMENDA- TION}

This study illustrates that the incidence of premarital sex is $29 \%$ affected by improper parenting patterns. Parents' knowledge about the importance of reproductive health still needs to be improved because the correct perceptions and attitudes of parents regarding premarital sexual behavior and it's control do not guarantee the implementation of prevention of sexual behavior in the adolescent. This can be seen from the lack of parents supervision on adolescent access to pornography which obtained through a variety of facilities provided by parents, including mobile phone and notebook along with the internet and private vehicles. So that parenting education is needed related to reproductive health communication and its impact as an effort to prevent premarital sex among adolescent.

Supervision on how children use some facilities which are given by their parents should be in the first place. Parents can make rules, such as night hour (not going outside over $8 \mathrm{PM}$ ) or punishment if their children access pornography content or it's found in their bag, phone or laptop. Besides that, parents need to increase their knowledge about reproductive health, so they can introduce sex education to their children in early ages. Furthermore, they need to be open-minded for hearing their children problems and giving some advice. By understanding both parents and children's role, the preventive action towards premarital sex behavior can be avoid in the future.

\section{ACKNOWLEDGEMENT}

"The research / publication of this article is supported by the United States Agency for International Development (USAID) through the Sustainable Hihger Education Research Alliance (SHERA) program, HIbah Number: AID497-A-00004, for the University of Indonesia (UI) entitled: Scientific Modeling, Application, Research, and Training for City-Centered Innovation and Technology (SMART CITY), Sub-Grant Number: IIE00000078-UI-1. “

\section{BIBLIOGRAPHY}

1. Musthofa SB, Winarti P. Faktor yang MemPengaruhi Perilaku Seks Pranikah Mahasiswa di Pekalongan tahun 2009-2010. J Kesehat Reproduksi. 2010;1(1):33-41.

2. Fajar NA. Analisis Bio, Psiko, Sosial, dan Spritual Pada Perilaku Seks Bebas Remaja Muslim Religius di Palembang. Universitas Airlangga; 2015.

3. Santrock JW. Remaja Jilid 1 Edisi 11. Jakarta: Erlangga. 2007;

4. Notobroto HB. Faktor yang Memengaruhi Perilaku Seksual Pranikah Remaja yang Bertunangan. Jurnal Biometrika dan Kependudukan. 2013;2(2):140-147.

5. Rohaya, Murdiningsih, Syarifah. Hubungan Faktor Orang Tua dan Faktor Lingkungan Dengan Pengetahuan Tentang Perilaku Seksual Bebas Pada Remaja Wanita di SMAN 3 dan SMA Methodist 1 Palembang Tahun 2006. Jurnal Kesehatan Kebidanan. 2006;1(13):1-6.

6. Aguma RP, Dewi AP. Hubungan Pola Asuh Orangtua Dengan Perilaku Seksual Remaja di SMA Tri Bhakti Pekanbaru. Jurnal Online Mahasiswa Bidang Ilmu Keperawatan. 2014;1(1):1-7. 
7. Williams TT, Pichon LC, Campbell B. Sexual health communication within religious African-American families. Journal Health Communication. 2015;30(4):328-338.

8. Anwar S. Hubungan Pola Asuh Orang Tua Dengan Motivasi Belajar Anak. Journal Pendidikan. 2017;1(2).

9. Gravel EE, Young MY, Darzi CM, Olavarria-Turner M, Lee AM-S. Premarital Sexual Debut in Emerging Adults of South Asian Descent: The Role of Parental Sexual Socialization and Sexual Attitudes. Journal Sexuality and Culture. 2016;20(4):862-878.

10. Ratnawati D, Rahmawati IL. Hubungan Komunikasi Efektif Orangtua Tentang Pendidikan Seks Dengan Perilaku Seks Bebas Pada Remaja Di SMA Kemala Bhayangkari 1 Jakarta Pada Bulan Juli Tahun 2015. Jurnal Keperawatan Widya Gantari Indonesia. 2019;2(2):63-79.

11. Teferra TB, Erena AN, Kebede A. Prevalence of Premarital Sexual Practice and Associated Factors among Undergraduate Health Science Students of Madawalabu University, Bale Goba, South East Ethiopia: Institution Based Cross Sectional Study. Pan Africa Medical Journal. 2015;20(1):1-11.

12. Wang N. Parent-Adolescent Communication About Sexuality in Chinese families. Journal of Family Communication. 2016;16(3):229246.

13. Titilayo O, Bose M, Olasumbo K, Ayomide O. Parents' Perception, Attitude and Practice towards Providing Sex Education for Adolescents in Eti-Osa local government area Lagos, Nigeria. IFE PsychologIA An International
Journal. 2019;27(1):45-50

14. Dinh T-H, van Teijlingen ER. Factors Influencing Engagement in Premarital Sex among Vietnamese Young Adults: a Qualitative Study. International Journal of Adolescent Medicine and Health. 2019;

15. Johan H, Irfan I, Reni DP. Correlation Between Parenting Types and Adolescence's Free Sex Behavior in SMK X Samarinda. International Journal of Nursing, Health Medicine. 2018;1(1):1-6.

16. Rudd KL, Alkon A, Yates TM. Prospective Relations between Intrusive Parenting and Child Behavior Problems: Differential Moderation by Parasympathetic Nervous System Regulation and Child Sex. Journal Physiology and Behavior. 2017;180:120-130.

17. Nursal DGA. Faktor-Faktor yang Berhubungan dengan Perilaku Seksual Murid SMU Negeri di Kota Padang tahun 2007. Jurnal Kesehatan Masyarakat Andalas. 2008;2(2):175180.

18. Hurlock EB. Psikologi Perkembangan: Suatu Pendekatan Sepanjang Rentang Kehidupan [Developmental Psychology: A Life-Span Approach](Istiwidayanti \& Doedjarwo, Trans.). Jakarta, Indonesia Erlangga. 2009;

19. Safa'ah N. Hubungan Pola Asuh Orang Tua Dengan Konsep Diri Pada Remaja Usia 15-18 Tahun Di SMA PGRI 1 Tuban. Jurnal Stikes NU Tuban. 2009; $1-7$

20. Fatchurahman M. Kepercayaan Diri, Kematangan Emosi, Pola Asuh Orang Tua Demokratis dan Kenakalan rRemaja. Persona Jurnal Psikologi Indonesia. 2012;1(2):77-87. 